\title{
Stability studies of chitosan-DNA-FAP-B nanoparticles for gene delivery to lung epithelial cells
}

\author{
ZOHREH MOHAMMADI ${ }^{1,2}$ \\ FARID ABEDIN DORKOOSH ${ }^{1}$ \\ SAMAN HOSSEINKHANI ${ }^{3}$ \\ TINA AMINI ${ }^{4}$ \\ AMIR ABBAS RAHIMI ${ }^{5}$ \\ ABDOLHOSSEIN ROUHOLAMINI NAJAFABADI ${ }^{1}$ \\ MORTEZA RAFIEE TEHRANI ${ }^{*}$ * \\ ${ }^{1}$ Department of Pharmaceutics, Faculty \\ of Pharmacy, Tehran University of \\ Medical Sciences, Tehran, Iran \\ ${ }^{2}$ Nanobiotechnology Research Center \\ Avicenna Research Institute, ACECR \\ Tehran, Iran \\ ${ }^{3}$ Department of Biochemistry, Faculty \\ of Science, Tarbiat Modares University \\ Tehran, Iran \\ ${ }^{4}$ Nobleceuticals Ltd, Birmingham \\ United Kingdom \\ ${ }^{5}$ Nanobiotechnology Department \\ Pasteur Institute of Iran, Tehran, Iran
}

\begin{abstract}
A successful gene delivery system requires efficiency and stability during storage. Stability studies are imperative for nanomedicines containing biotechnological products such as plasmids and targeting peptides. Chitosan-DNA-FAP-B nanoparticles are novel non-viral vectors for specific gene delivery to the lung epithelial cells. In this study, the storage stability of chitosan-DNA-FAP-B nanoparticles at $-20,5$ and $24{ }^{\circ} \mathrm{C}$ was examined. Size, zeta potential and transfection efficiency of these nanoparticles in storage were also evaluated. Stability studies showed that chitosan-DNA-FAP-B nanoparticles were stable after 1 month when stored at $-20^{\circ} \mathrm{C}$ and retained their initial size, zeta potential and transfection efficiency. However, their stability was not desirable at 5 and $24^{\circ} \mathrm{C}$. Based on these results, it can be concluded that chitosan-DNA-FAP-B nanoparticles can be a promising candidate for gene delivery to lung epithelial cells with good storage stability at $-20{ }^{\circ} \mathrm{C}$ during 1 month.
\end{abstract}

Keywords: chitosan, FAP-B, nanoparticle, stability, gene delivery

The aim of gene delivery is to transfer genetic materials into target cells and alter their function. Chitosan is a non-toxic biodegradable polymer. Its cationic polyelectrolyte nature provides a strong electrostatic interaction with negatively charged DNA (1) and protects it from nuclease degradation (2). This makes chitosan a good candidate for non-viral gene delivery (3). Researchers have modified this polymer in order to get effective transfection. One of these modifications was quaternizing of the polymer.

\footnotetext{
*Correspondence; e-mail: rafitehr@ams.ac.ir
} 
$N, N$-diethyl- $N$-methyl chitosan was one of the quaternized chitosan derivatives that was successfully used for gene delivery to human pancreatic cancer cells in our laboratory (4). Another attempt leading to improvement of chitosan mediated gene delivery was the introduction of targeting ligands to the polymer. Fibronectin Attachment Protein of BCG (FAP-B) is one of the most expressed surface proteins of Mycobacterium bovis (BCG); it is responsible for the attachment of many mycobacteria onto the fibronectin molecule of epithelial cells' membranes. It has recently been demonstrated that the presence of this molecule on BCG bacilli is a key element in the process of BCG entry into the epithelial cells (5). In a previous study in our laboratory, chitosan-DNA-FAP-B nanoparticles, as a new non-viral gene delivery system to lung epithelial cells, were prepared and investigated (6). In vivo transfection efficiency of these nanoparticles was investigated in another study in our laboratory (7).

All nanomedicines should be evaluated for their thermal stability under storage conditions (8). In general, long-term and accelerated storage conditions recommended by $\mathrm{ICH}$ guidelines (9) for drug products intended for storage in a refrigerator are $5 \pm 3{ }^{\circ} \mathrm{C}$ and $25 \pm 2{ }^{\circ} \mathrm{C} / 60 \pm 5 \% \mathrm{RH}$, respectively. If drug products are intended for storage in a freezer, only long-term storage conditions of $-20 \pm 5{ }^{\circ} \mathrm{C}$ are recommended.

In the present study, stability of chitosan-DNA-FAP-B nanoparticles was investigated according to the ICH guidelines. Size, zeta potential, gene transfer efficiency and DNA binding ability of nanoparticles were evaluated during the storage period of stability studies.

\section{EXPERIMENTAL}

\section{Materials}

Chitosan Chitoclear $\left(M_{\mathrm{r}}=126 \mathrm{kDa}\right.$, deacetylation degree $\left.98 \%\right)$ was purchased from Primex (Iceland). The plasmid pGL3-control vector encoding firefly luciferase driven by an SV40 promoter was purchased from Promega (USA). FAP-B (Fibronectin Attachment Protein of BCG) was kindly provided by Prof G. Marchal (Institut Pasteur, Paris, France) (10). Turbofect reagent was obtained from Fermentase (Thermo Fisher Scientific, Canada). Cell culture media: Dulbecco's Modified Eagle's Medium (DMEM) and the penicillin-streptomycin mixture (PS) were obtained from Gibco (Invitrogen, Singapore). Fetal bovine serum (FBS) was purchased from Hyclone (Research Instrument, Singapore). Sodium acetate, sodium sulfate, sodium hydroxide and other chemicals were purchased from Merck (Germany).

\section{Amplification and purification of DNA plasmid}

The plasmid pGL3-control vector encoding firefly luciferase driven by an SV40 promoter (Promega, USA) was amplified in E. coli JM107 bacteria (ATCC 47014, Sigma, USA) and was purified using the endo free Maxi prep plasmid extraction kit (Bioneer, South Korea) according to the manufacturer's instructions. The plasmid was quantified and qualified using a spectrophotometer (Nanodrop 2000, Thermo Scientific, USA) and electrophoresis (Bio-Rad, USA) in $1 \%$ agarose gel, respectively. 


\section{Preparation of chitosan-DNA-FAP-B nanoparticles}

A chitosan solution of $0.047 \mathrm{mg} \mathrm{mL}^{-1}$ in $5 \mathrm{mmol} \mathrm{L}^{-1}$ sodium acetate buffer, $\mathrm{pH}=5.5$, was prepared in order to achieve the N/P ratio of 20 (an amino group to a phosphate group ratio is hereafter defined as charge or $\mathrm{N} / \mathrm{P}$ ratio). A DNA solution of $50 \mu \mathrm{g} \mathrm{mL}-1$ in $25 \mathrm{mmol} \mathrm{L}^{-1}$ of sodium sulfate was prepared. Solutions were preheated to $50-55^{\circ} \mathrm{C}$ separately. Equal volumes of chitosan solution and DNA solution were added together under stirring. The final volume of the mixture was limited to below $500 \mu \mathrm{L}$ in order to yield uniform nanoparticles. After preparation of chitosan-DNA nanoparticles, solution $\mathrm{pH}$ was adjusted to 8 by adding $\mathrm{NaOH}$. An FAP-B solution of $120 \mu$ g per $100 \mu \mathrm{L}$ in deionized sterile water was prepared. One mole of FAP-B $\left(M_{\mathrm{r}}=45 \mathrm{kDa}\right)$ was added to a nanoparticle solution equal to 1 mole chitosan $\left(M_{\mathrm{r}}=126 \mathrm{kDa}\right)$. The mixture was incubated at room temperature and stirred $(500 \mathrm{rpm})$ for 24 hours. The resulting solution was then centrifuged for $6 \mathrm{~min}$ at room temperature at a speed of $6740 \times g$. To remove possible aggregates during high speed centrifugation, a soft stirring process (speed of $500 \mathrm{rpm}$ for 24 hour) was performed (6).

\section{Characterization of chitosan-DNA and chitosan-DNA-FAP-B nanoparticles}

The size of nanoparticles was determined by photon correlation spectroscopy (PCS) and zeta potential by laser doppler velocimetry (LDV) using a Zetasizer Nano ZS ZEN 3600 (Malvern Instruments, UK). Size measurement was performed at $25^{\circ} \mathrm{C}$, using a 633 $\mathrm{nm}$ red laser and was recorded for $180 \mathrm{~s}$ for each measurement. The viscosity of samples was $0.88 \mathrm{~Pa} \mathrm{~s}$ and the refractive index of the solvent was 1.33 . The mean hydrodynamic diameter was generated by cumulative analysis using Malvern software. The results were acceptable if they had polydispersity indices below 0.5 . Zeta potential measurements were performed using an aqueous dip cell in the automatic mode.

\section{Agarose gel electrophoresis}

The DNA binding ability of chitosan was evaluated by agarose gel electrophoresis. The complexes containing $0.5 \mathrm{mg}$ of DNA were loaded into individual wells of $1.0 \%$ agarose gel in 1-Tris-boric acid-EDTA buffer, electrophoresed at $80 \mathrm{~V}$ for $45 \mathrm{~min}$, and stained with $0.5 \mathrm{mg} \mathrm{mL}^{-1}$ ethidium bromide. The resulting DNA migration pattern was revealed under UV irradiation.

\section{In vitro transfection of A549 cells with chitosan-DNA-FAP-B nanoparticles}

Cell culture. - The cells (A549: alveolar epithelial cells obtained from the Pasteur Institute of Iran, Tehran, Iran) were seeded $48 \mathrm{~h}$ prior to transfection in 24 -well plates at a density of 40,000 cells per well in $1 \mathrm{~mL}$ of DMEM supplemented with $10 \%$ FBS and $1 \%$ PS. On the day of transfection, the culture medium in each well was replaced with $1 \mathrm{~mL}$ of complete medium containing naked DNA $(1 \mu \mathrm{g})$ or chitosan-DNA nanoparticles (negative controls) or chitosan-DNA-FAP-B nanoparticles (tests). The amount of nanoparticles added to each well was equivalent to $1 \mu \mathrm{g}$ of DNA. The cells were then incubated until $48 \mathrm{~h}$ post transfection. Turbofect was used as positive control according to the manufacturer's procedures. Each well received $2 \mu \mathrm{L}$ of Turbofect complexed with $1 \mu \mathrm{g}$ of DNA. 


\section{Luminometric assay for luciferase}

After $48 \mathrm{~h}$ incubation, cells were rinsed with sterile phosphate buffer $(\mathrm{pH}=7.4)$ and permeabilized with $80 \mu \mathrm{L}$ of cell lysis buffer purchased from Promega (USA) (while the plate was placed in ice). The plate was shaken for 15 minutes after which the cells were centrifuged for $2 \mathrm{~min}$ at $19837 \times g$. The pellet was sonicated for $2 \mathrm{~s}$ while the tube was on ice. Sonication was repeated 4 times (it was found that the best dispersion occurred after the fourth sonication). The luminometric assay for luciferase gene expression in cell extracts was measured using a luminometer (Berthold systems $\mathrm{GmbH}$, Germany) for 10 seconds per well. Results were expressed as relative light units (RLU per $10 \mathrm{~s}$ ).

\section{Stability of chitosan-DNA-FAP-B nanoparticles}

Five $\mathrm{mL}$ of chitosan-DNA-FAP-B nanoparticles were transferred to clear glass-vials and kept at 5 and $25^{\circ} \mathrm{C}$ for 6 months and at $-20^{\circ} \mathrm{C}$ for a year $(8,9)$. Samples were withdrawn at predetermined time intervals $(0,1,3,6$ months and 12 months for frozen sample). Measuring the size and zeta potential of polyplexes, DNA binding ability of chitosan and in vitro transfection efficiency of nanoparticles were evaluated as described previously.

\section{Statistical analysis}

All experiments were repeated at least three times. Data are expressed as mean \pm standard deviations. Statistical analysis was performed using Student's $t$-test.

\section{RESULTS AND DISCUSSION}

\section{Preparation and characterization of chitosan-DNA-FAP-B nanoparticles}

Chitosan-DNA nanoparticles were formed as a result of complex coacervation between chitosan and DNA $(11,12)$. Chitosan-DNA nanoparticles were prepared at the N/P ratio of 20, which proved to result in optimal nanoparticles with regard to size $(227 \pm 43 \mathrm{~nm})$ and positive surface charge $(+17.8 \pm 3.2 \mathrm{mV})$.

Chitosan-DNA-FAP-B nanoparticles were prepared and evaluated as previously described (6). Nanoparticles containing plasmids at the N/P ratio of 20 were complexed with FAP-B via electrostatic interaction. After complexation, the size and zeta potential of the resulting nanoparticles were $279 \pm 27 \mathrm{~nm}$ and $-2.3 \pm 1.5 \mathrm{mV}$, respectively.

\section{Transfection efficiency of chitosan-DNA-FAP-B nanoparticles}

The in vitro transfection ability of chitosan-DNA-FAP-B nanoparticles was first evaluated in alveolar epithelial cells (A549) using the luciferase plasmid as previously described (6). Results of the luminescence assay in the transfected cells indicated relatively high transfection efficiency. The expressed transfection efficiency was about 10-fold higher than the background level of chitosan-DNA nanoparticles (Fig. 1). This increase in transfection efficiency of chitosan-DNA-FAP-B nanoparticles was due to the specific interaction of FAP-B with its receptors at the surface of alveolar epithelial cells (6). 
Fig. 1. In vitro transfection efficiency. A: naked DNA, B: chitosan-DNA nanoparticles, C: chitosan-DNA-FAP-B nanoparticles, D: Turbofect.

Mean \pm SD, $n=3$.

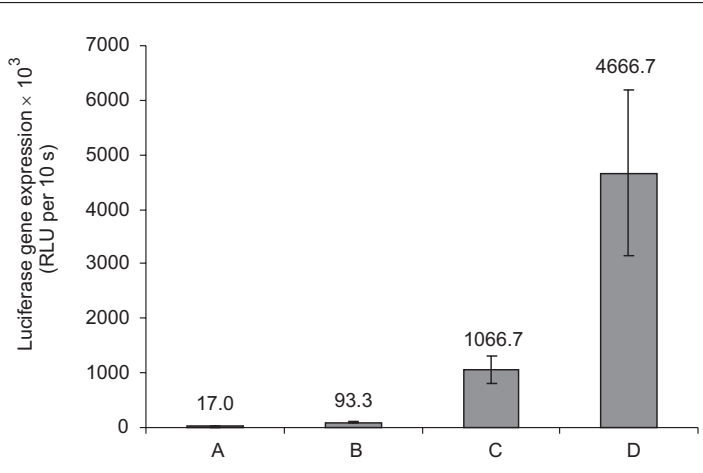

\section{Stability of chitosan-DNA-FAP-B nanoparticles}

A successful gene delivery system requires efficiency and stability during storage. This is why stability studies are imperative for new pharmaceutical products. Targeted nanomedicines are mostly incorporated into biotechnological products such as targeting peptides or loaded with proteins and genes. According to the ICH guideline Q5C, parameters such as physical appearance and morphology, particle size, size distribution and surface charge (8) are to be evaluated. An additional parameter applicable is the potency of the biotechnological product (13). Thermal stability of chitosan-DNA-FAP-B nanoparticles at three temperatures $\left(24,5\right.$ and $\left.-20^{\circ} \mathrm{C}\right)$ was investigated according to ICH guidelines (9).

Results showed that, after 1 month, the size of chitosan-DNA-FAP-B nanoparticles stored at $24{ }^{\circ} \mathrm{C}$ was smaller than initial nanoparticles (Fig. 2) and their zeta potential changed from initially negative to positive $(-2.3 \pm 1.5$ and $+3.0 \pm 0.5 \mathrm{mV}$ respectively) (Fig. 3). These findings indicate that FAP-B was dissociated after 1 month at $24{ }^{\circ} \mathrm{C}$, which led to smaller nanoparticles with a positive charge. FAP-B further degraded over the time and, at 3- and 6-month time points, the size of nanoparticles was further reduced and their surface charge became more positive (Fig. 3).

Transfection studies confirmed the above results (Fig. 4). After 1 month at $24{ }^{\circ} \mathrm{C}$, transfection efficiency of chitosan-DNA-FAP-B nanoparticles $\left(8.6 \times 10^{4}\right.$ RLU per $\left.10 \mathrm{~s}\right)$ was not significantly different from chitosan-DNA nanoparticles $\left(9.3 \times 10^{4} \mathrm{RLU}\right.$ per $\left.10 \mathrm{~s}\right)$ (Fig. 1), indicating that FAP-B dissociated after 1 month and, in fact, there were chito-

Fig. 2. Particle size of nanoparticles stored at $24{ }^{\circ} \mathrm{C}(\bullet), 5{ }^{\circ} \mathrm{C}(\boldsymbol{\square})$ and $-20{ }^{\circ} \mathrm{C}(\boldsymbol{\Delta})$. Mean $\pm \mathrm{SD}, n=3$.

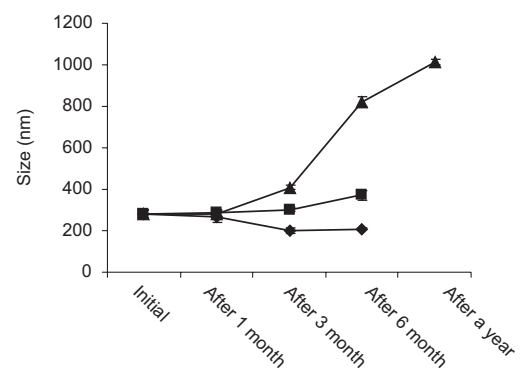




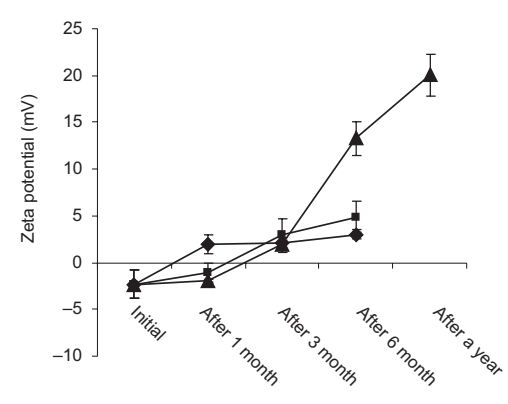

Fig. 3. Zeta potential of nanoparticles stored at 24 ${ }^{\circ} \mathrm{C}(\bullet), 5^{\circ} \mathrm{C}(\boldsymbol{\square})$ and $-20{ }^{\circ} \mathrm{C}(\boldsymbol{\Delta})$. Mean $\pm \mathrm{SD}, n=3$.

san-DNA nanoparticles in the medium of cell culture without any FAP-B. After 3 months at that temperature, transfection efficiency was further reduced and after 6 months the luciferase gene expression of nanoparticles was close to zero (Fig. 4). Agarose gel electrophoresis results showed that after 1 month at $24{ }^{\circ} \mathrm{C}$ plasmid could remain within the loading well (Fig. 5a), whereas after 3 months chitosan could not condense the plasmid (Fig. 5b). In addition, after 6 months, no plasmid band was perceived in the agarose gel (Fig. 5c). These observations indicated that chitosan also dissociated after 3 months and was unable to condense DNA and therefore transfection efficiency was considerably reduced. After 6 months, the plasmid seemed to be totally degraded by nuclease enzymes, since there was no plasmid band in the agarose gel and the transfection efficiency was close to zero.

The size of nanoparticles stored at $5{ }^{\circ} \mathrm{C}$ increased over the storage time (Fig. 2), possibly due to aggregation. The results show that when stored at $5{ }^{\circ} \mathrm{C}, \mathrm{FAP}-\mathrm{B}$ was dissociated after 3 months, resulting in positively charged nanoparticles. Transfection studies showed that the luciferase gene expression of nanoparticles was reduced by half after 1 month (Fig. 4). Thus, it can be concluded that FAP-B dissociated only partially. After 3 months, transfection efficiency became very low, indicating complete dissociation of FAP-B, which led to nanoparticles with positive zeta potential $(+2.9 \pm 1.9 \mathrm{mV})$. At that point, chitosan also dissociated since it could not condense the plasmid at the agarose gel (Fig. 5b). Nanoparticles stored at $5{ }^{\circ} \mathrm{C}$ did not show any transfection efficiency after 6 months (Fig. 4) and did not show any band in the agarose during electrophoresis studies (Fig. 5c). It can therefore be concluded that plasmid was degraded after 6 months at $5{ }^{\circ} \mathrm{C}$.

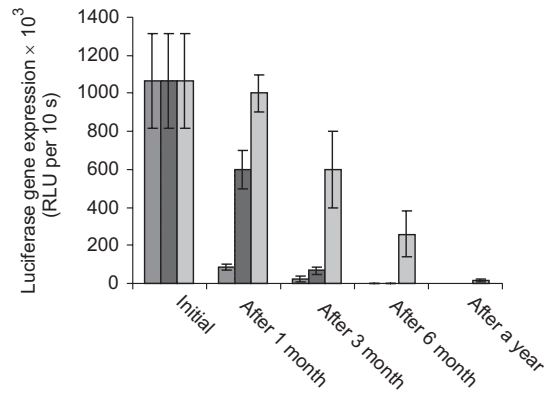

Fig. 4. In vitro transfection efficiency of nanoparticles stored at $24 \square, 5 \square$ and $-20 \square$. Mean $\pm \mathrm{SD}, n=3$. 

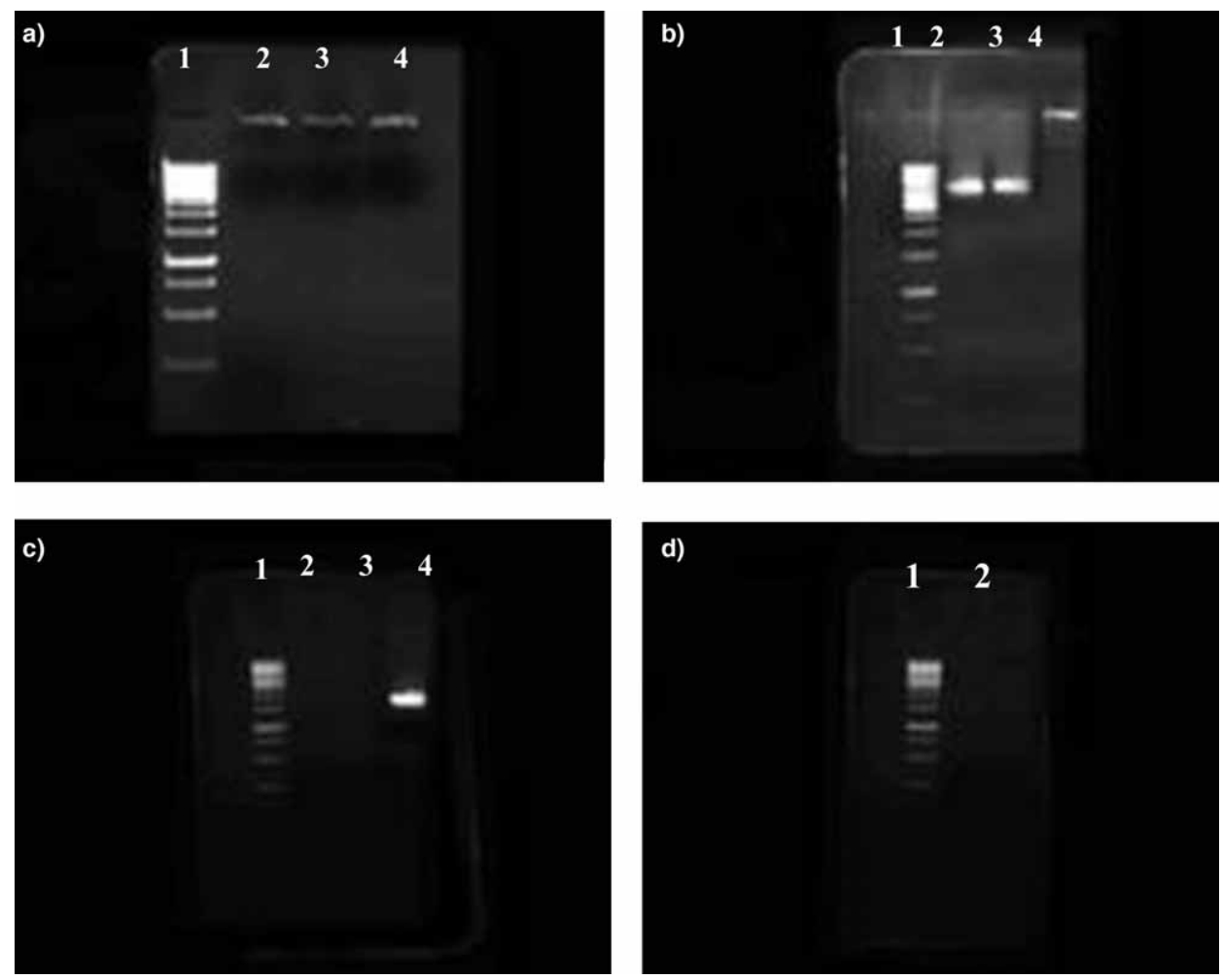

Fig. 5. Gel retarding analysis of chitosan-DNA-FAP-B nanoparticles: a) after 1 month, b) after 3 months, c) after 6 months, d) after a year. Lane 1: ladder, lane 2: nanoparticles stored at $24^{\circ} \mathrm{C}$, lane 3: nanoparticles stored at $5{ }^{\circ} \mathrm{C}$, lane 4 : nanoparticles stored at $-20^{\circ} \mathrm{C}$.

Stability studies of nanoparticles stored at $-20{ }^{\circ} \mathrm{C}$ showed a gradual increase in size over a year (from $279 \pm 22$ to $1015 \pm 14 \mathrm{~nm}$ ) (Fig. 2), which could be due to their aggregation. The zeta potential of these nanoparticles changed from $-2.3 \pm 1.5$ to $+20.0 \pm 2.3 \mathrm{mV}$ after a year (Fig. 3), which can be the result of FAP-B dissociation. According to Fig. 3, nanoparticles stored at $-20{ }^{\circ} \mathrm{C}$ were negatively charged after 1 month indicating that FAP-B was still present at the surface of nanoparticles. However, surface charge variation from negative to positive after 3 months showed that FAP-B had dissociated. Transfection efficiency of chitosan-DNA-FAP-B nanoparticles stored at $-20^{\circ} \mathrm{C}$ (Fig. 4) after 1 month $\left(10.0 \times 10^{5}\right.$ RLU per $\left.10 \mathrm{~s}\right)$ remained comparable to that of the initial nanoparticles $\left(10.6 \times 10^{5} \mathrm{RLU}\right.$ per $\left.10 \mathrm{~s}\right)$. After 3 months, this amount was further reduced (6.0 $\times 10^{5}$ RLU per $10 \mathrm{~s}$ ) due to the dissociation of FAP-B. Luciferase activity of nanoparticles declined gradually until it reached zero after a year. This could be due to dissociation of chitosan and degradation of plasmid during the storage period. According to the agarose gel electrophoresis studies, plasmid could remain within the loading well after 1 and 3 months storage at $-20^{\circ} \mathrm{C}$ (Figs. $5 \mathrm{a}$ and b) but after 6 months chitosan could not 
condense the plasmid, indicating its dissociation (Fig. 5c). In addition, after a year, there was no band in the agarose gel as the result of plasmid degradation (Fig. 5d).

During the storage of chitosan-DNA-FAP-B nanoparticles, FAP-B, chitosan and DNA can be dissociated or degraded. Long-term stability of proteins such as FAP-B can be affected by some reactions, which can lead to their degradation. The most important reactions that change the structure and function of proteins can be summarized as follows: fragmentation of peptide molecules due to hydrolysis of peptide bound ( $\mathrm{R}-\mathrm{NH}-$ -CO-R), oxidation of free sulfohydryl groups of cysteinyl residues, oxidations of sulfur moiety in a thio-ether linkage of methionyl residues, nitrogen $(\mathrm{N})$ to oxygen $(\mathrm{O})$ migration and $\alpha$-carboxy to $\beta$-carboxy migration of the peptide linkage (14). Chitosan molecules are also affected by long-term storage. Since chitosan is a biodegradable polymer, its chemical structure [poly(N-glucosamine)] can be degraded or dissociated by some enzymes (15). Glycoside bounds in the chitosan structure can be destroyed during storage, which stops this polymer from playing its role as a condensing agent. The last molecule that is influenced by long-term storage is plasmid. Since chitosan can protect plasmid from degradation enzymes (16), plasmid was only degraded after FAP-B and chitosan were degraded. Degradation of plasmid leads to changes in DNA structure from supercoiled to open circular or linear DNA (17). Due to the fact that the supercoiled structure of DNA is necessary for efficient gene delivery (18), changes in DNA structure lead to lack of transfection efficiency.

\section{CONCLUSIONS}

Chitosan-DNA nanoparticles were successfully prepared by a complex coacervation process under defined conditions. FAP-B was added to the chitosan-DNA nanoparticles as a ligand for attachment to its specific receptors present at the surface of lung epithelial cells. Stability studies of chitosan-DNA-FAP-B nanoparticles showed that the nanoparticles were not stable at 24 and $5^{\circ} \mathrm{C}$, and their stability was desirable only at $-20^{\circ} \mathrm{C}$ for 1 month. This study suggested that the stability of chitosan-FAP-B nanoparticles, as a promising carrier for targeted gene delivery to fibronectin molecules (FAP-B receptors) of epithelial cell membranes, could be improved by adaptation of their final formulation such as adding stabilizers to the formulation or lyophilizing the product to avoid possible dissociation or degradation.

Acknowledgements. - This work would not have been possible without the invaluable excellent technical assistance of the following colleagues, Dr. Khanahmad and Miss Sohrabi. This work was supported by the Pasteur Institute of Iran and Tehran University of Medical Sciences (grant 57-6858).

\section{REFERENCES}

1. S. Mansouria, Y. Cuieb, F. Winnikb, Q. Shia, P. Lavignea, M. Benderdoura, E. Beaumonta and J. C. Fernandes, Characterization of folate-chitosan-DNA nanoparticles for gene therapy, Biomaterials 27 (2006) 2060-2065; DOI: 10.1016/j.biomaterials.2005.09.020. 
2. Z. Cui and R. J. Mumper, Chitosan-based nanoparticles for topical genetic immunization, J. Control. Release 75 (2001) 409-419; DOI: 10.1016/s0168-3659(01)00407-2.

3. F. C. MacLaughlin, R. J. Mumper, J. Wang, J. M. Tagliaferri, I. Gill, M. Hinchcliffe and A. P. Rolland, Chitosan and depolymerized chitosan oligomers as condensing carriers for in vivo plasmid delivery, J. Control. Release 56 (1998) 259-272; DOI: 10.1016/s0168-3659(98)00097-2.

4. S. Safari, F. A. Dorkoosh, M. Soleimani, M. H. Zarrintan, H. Akbari, B. Larijani and M. Rafiee Tehrani, N-Diethylmethyl chitosan for gene delivery to pancreatic cancer cells and the relation between charge ratio and biologic properties of polyplexes via interpolations polynomial, Int. J. Pharm. 420 (2011) 350-357; DOI: 10.1016/j.ijpharm.2011.08.050.

5. M. Abolhassani, M. Lagranderie, I. Caminshi, F. Romain, A. Balazuc, M. Wagner, M. Tanguy, L. Fiette, I. Sobhani, G. Milon and G. Marchal, Similar functional activity of dendritic cells recruited to the mesenteric lymph nodes of newborn and adult mice after the rectal delivery of $\mathrm{Myco-}$ bacterium bovis BCG, Microbes Infect 8 (2006) 2341-2351; DOI: 10.1016/j.micinf.2006.03.022.

6. Z. Mohammadi, M. Abolhassani, F. A. Dorkoosh, S. Hosseinkhani, K. Gilani, T. Amini, A. Rouholamini Najafabadi and M. Rafiee Tehrani, Preparation and evaluation of chitosan-DNA-FAP-B nanoparticles as a novel non-viral vector for gene delivery to the lung epithelial cells, Int. J. Pharm. 409 (2011) 307-313; DOI:10.1016/j.ijpharm.2011.02.043.

7. Z. Mohammadi, F. A. Dorkoosh, S. Hosseinkhani, K. Gilani, T. Amini, A. Rouholamini Najafabadi and M. Rafiee Tehrani, In vivo transfection study of chitosan-DNA-FAP-B nanoparticles as a new non viral vector for gene delivery to the lung, Int. J. Pharm. 421 (2011) 183-188; DOI: 10.1016/ j.ijpharm.2011.09.029.

8. M. S. Muthu and S. Feng, Pharmaceutical stability aspects of nanomedicines, Nanomedicine 4 (2009) 857-860; DOI:10.2217/nnm.09.75.

9. International Conference on Harmonization, ICH Q1A (R2), Stability Testing Guidelines: Stability Testing of New Drug Substances and Products, ICH step 5, CPMP/ICH/2736/99, London 2003.

10. F. Romain, A. Laqueyrerie, P. Militzer, P. Pescher, P. Chavarot, M. La-Granderie, G. Auregan, M. Gheorghiu and G. Marchal, Identification of a Mycobacterium bovis BCG 45/47-kilodalton antigen complex, an immunodominant target for antibody response after immunization with living bacteria, Infect. Immun 61 (1993) 742-750.

11. M. Elfinger, J. Geiger, G. Hasenpusch, S. Üzgün, N. Sieverling, M. K. Aneja, C. Maucksch and C. Rudolph, Targeting of the $\beta 2$-adrenoceptor increases nonviral gene delivery to pulmonary epithelial cells in vitro and lungs in vivo, J. Control. Release 135 (2009) 234-241; DOI: 10.1016/j. jcourel.2009.01.012.

12. H. Mao, K. Roy, V. Troung-Le, K. A. Janes, K. Y. Lin, Y. Wang, J. T. August and K. W. Leong, Chitosan-DNA nanoparticles as gene carriers: synthesis, characterization and transfection efficiency, J. Control. Release 70 (2001) 399-421; DOI: 10.1016/s0168-3659(00)00361-8.

13. International Conference on Harmonization, ICH Q5C, Stability Testing of Biotechnological/Biological Products, ICH step 4, CPMP/ICH/138/95, London 1996.

14. T. Arakawa, S. J. Prestrelski, W. C. Kenney and J. F. Carpenter, Factors affecting short-term and long-term stabilities of proteins, Adv. Drug Deliver. Rev. 46 (2001) 307-326; DOI: 10.1016/s0169$-409 x(00) 00144-7$.

15. G. Borchard, Chitosans for gene delivery, Adv. Drug Deliver. Rev. 52 (2001) 145-150; DOI: 10.1016/ s0169-409x(01)00198-3.

16. H. Okamoto, Y. Sakakura, K. Shiraki, K. Oka, S. Nishida, H. Todo, K. Iida and K. Danjo, Stability of chitosan-pDNA complex powder prepared by supercritical carbon dioxide process, Int. J. Pharm 290 (2005) 73-81; DOI: 10.1016/j.ijpharm.2004.11.026.

17. W. Walther, U. Stein, C. Voss, T. Schmidt, M. Schleef and P. M. Schlag, Stability analysis for long-term storage of naked DNA: impact on nonviral in vivo gene transfer, Anal. Biochem 318 (2003) 230-235; DOI: 10.1016/s0003-2697(03)00244-6. 
Z. Mohammadi et al.: Stability studies of chitosan-DNA-FAP-B nanoparticles for gene delivery to lung epithelial cells, Acta Pharm. 62 (2012) 83-92.

18. D. M. Prazeres, G. N. M. Ferreira, G. A. Monteiro, C. L. Cooney and J. M. S. Cabral, Large-scale production of pharmaceutical-grade plasmid DNA for gene therapy: problems and bottlenecks, Trends Biotechnol. 17 (1999) 169-174; DOI: 10.1016/s0167-7799(98)01291-8.

\author{
$S A \check{Z} E T A K$
}

\title{
Ispitivanje stabilnosti kitozanskih nanočestica s DNA-FAP-B za gensku isporuku u epitelne stanice pluća
}

\begin{abstract}
ZOHREH MOHAMMADI, FARID ABEDIN DORKOOSH, SAMAN HOSSEINKHANI, TINA AMINI, AMIR ABBAS RAHIMI, ABDOLHOSSEIN ROUHOLAMINI NAJAFABADI i MORTEZA RAFIEE TEHRANI
\end{abstract}

Dobar sustav za gensku isporuku mora biti učinkovit i stabilan prilikom skladištenja. Stoga su ispitivanja stabilnosti nužna za nonosustave s biotehnološkim produktima kao što su plazmidi i ciljni peptidi. Kitozanske nanočestice s DNA-FAP-B su novi nevirusni vektori za specifičnu gensku isporuku u epitelne stanice pluća. U radu je ispitana njihova stabilnost na $-20,5$ i $24{ }^{\circ} \mathrm{C}$, veličina čestica, zeta potencijal i transfekcijska učinkovitost. Dobiveni rezultati pokazuju da su kitozanske nanočestice s DNA-FAP-B stabilne nakon mjesec dana skladištenja na $-20{ }^{\circ} \mathrm{C}$ i da zadržavaju početnu veličinu, zeta potencijal i sposobnost transfekcije, a nisu stabilne skladištenjem na 5 i $24^{\circ} \mathrm{C}$. Može se zaključiti da su kitozanske nanočestice s DNA-FAP-B potencijalni kandidati za gensku isporuku u epitelne stanice pluća te da su dovoljno stabilne ako se skladište mjesec dana na $-20{ }^{\circ} \mathrm{C}$.

Ključne riječi: kitozan, FAP-B, nanočestica, stabilnost, genska isporuka

Department of Pharmaceutics, Faculty of Pharmacy, Tehran University of Medical Sciences, Tehran, Iran

Nanobiotechnology Research Center, Avicenna Research Institute, ACECR, Tehran, Iran

Department of Biochemistry, Faculty of Science, Tarbiat Modares University, Tehran, Iran

Nobleceuticals Ltd, Birmingham, United Kingdom

Nanobiotechnology Department, Pasteur Institute of Iran, Tehran, Iran 